\title{
EL ACCESO AL GOBIERNO \\ DE LAS CIUDADES CASTELLANAS CON VOTO EN CORTES A TRAVÉS DEL PATRONAZGO REGIO DURANTE EL SIGLO XV
}

\author{
MÁXIMO DIAGo HERNANDO ${ }^{1}$
}

Fecha de recepción: mayo 2002

Fecha de aceptación y versión final: julio 2002

Resumen: Se demuestra que en Castilla durante el siglo XV el grupo más influyente en el gobierno de las principales ciudades, y en concreto de las diecisiete que tenían voto en Cortes, estuvo constituido por individuos que estaban al servicio de los reyes en los órganos de gobierno y administración central y territorial del reino. Se da cuenta de los mecanismos institucionales que propiciaron esta situación, y se destaca la importancia que tuvo la creación de nuevos oficios de regidor por los reyes. Se demuestra además que las familias más influyentes de este grupo de servidores del rey consiguieron acumular oficios de regidores en varias de estas ciudades, contribuyendo así a reforzar los vínculos políticos de éstas entre sí y con la propia monarquía.

Palabras clave: Castilla, siglo XV, ciudades, gobierno urbano, oligarquías urbanas.

Abstract: The author proves that the most influential group in the government of the Castilian towns during the fifteenth century, and most of all in the seventeen towns that had the right to send deputies to Parliament (Cortes), was constituted by individuals that worked at the service of the king in the main organs of central and territorial government and administration of the kingdom. He gives account of the institutional mechanism that propitiated this situation, and he stresses the significance of the creation by the king of new offices of "regidores" (aldermen). He also proves that the most influential families of this group of king's servants accumulated posts of "regidores" (aldermen) in several towns, and contributed in this way to reinforce the political links that these towns established with each other and with the monarchy.

Key-words: Castile, fifteenth century, towns, urban government, urban oligarchies.

${ }^{1}$ Instituto de Historia, CSIC. Madrid.

«Anuario de Estudios Medievales*, 32/2 (2002), pp. 879-913.- ISSN 0066-5061. 
1. El marco institucional: los ayuntamientos cerrados de regidores vitalicios.- 2. Procedimientos de selección de regidores previos al nombramiento regio.- 3 . La intervención directa de la monarquía en la selección de regidores mediante la creación de oficios acrecentados.- 4. Predominio de los individuos vinculados a la monarquía en los regimientos de las principales ciudades castellanas durante el siglo XV.- 5. Conclusión.- Bibliografía.

Las ciudades castellanas adoptaron en el siglo XV un perfil sociopolítico e institucional bastante singular, que ofrecía notables contrastes con el que ofrecieron por la misma época los principales núcleos urbanos en otros ámbitos del continente europeo y, dentro de la Península Ibérica, en los diversos reinos de la Corona de Aragón. En el transcurso de dicho siglo, en concreto, las ciudades realengas de Castilla vieron sensiblemente reducida su capacidad de participación en la toma de decisiones políticas al más alto nivel en las instancias centrales de gobierno del reino, puesto que la mayor parte de ellas pasaron a quedar privadas del derecho de enviar representantes a las reuniones de Cortes, única institución que en la Corona de Castilla proporcionaba a la población ciudadana una cauce para intervenir en los procesos de toma de tales decisiones, aunque de forma ciertamente cada vez más pasiva. A partir del reinado de Juan II, en efecto, se consolidó la costumbre de que el rey convocase sólo a diecisiete ciudades a las sesiones de Cortes, mientras que las demás ciudades del realengo, que en los siglos anteriores habían enviado con más o menos asiduidad sus procuradores a dichas sesiones, ya no pudieron hacerlo más, y dejaron de constituir interlocutores válidos para la monarquía.

Las diecisiete ciudades que en el siglo XV consolidaron su derecho a estar representadas en las asambleas de Cortes, a las cuales, en 1492, se sumó la de Granada, pasaron a conformar a partir de entonces un grupo bien diferenciado dentro del conjunto de ciudades realengas castellanas, porque pudieron mantener una relación política más estrecha e intensa con la monarquía. Y esta intensificación y fortalecimiento del vínculo político entre ambas instancias fue sin duda propiciada por la necesidad sentida por la propia monarquía de asegurarse una mayor capacidad de intervención en las instituciones de gobierno de estas ciudades, para evitar que desde ellas se 
alimentase una corriente de oposición política que adecuadamente canalizada por los procuradores en Cortes pudiese llegar a tener efectos subversivos. Puesto que, en efecto, como muy bien pusieron de manifiesto los acontecimientos ocurridos durante el año 1520 , este peligro no era ficticio sino muy real.

Por ello, a la hora de abordar desde una perspectiva global el estudio de la procedencia social de los grupos gobernantes de las ciudades castellanas bajomedievales, ofrece un indiscutible interés dedicar un trabajo monográfico a las ciudades con voto en Cortes, para determinar en qué medida la singularidad que les confería el disfrute de este privilegio tuvo también su traducción en la presencia de rasgos singulares en el perfil sociopolítico de sus grupos gobernantes.

La clarificación de esta problemática exige, sin embargo, llevar a cabo un exhaustivo trabajo de historia comparada de las estructuras sociales de diecisiete ciudades, dejando a un lado Granada, que se incorporó al grupo en fecha muy tardía, que se ha de basar preferentemente en la información aportada por los trabajos monográficos de historia local hasta ahora publicados. Y esta información es de carácter muy desigual, ya que no en todas las ciudades se ha conseguido con igual fortuna profundizar en la caracterización del perfil sociopolítico de sus oligarquías, entre otras muchas razones porque las limitaciones impuestas para la realización de esta tarea por la documentación disponible alcanzan muy diversa envergadura según la ciudad de que se trate.

En el estado actual de la investigación no resulta posible, por tanto, ofrecer una visión de conjunto bien fundamentada sobre las singularidades del perfil sociopolítico de las oligarquías de las ciudades castellanas con voto en Cortes durante el siglo XV. Y, por este motivo, el objetivo que nos hemos propuesto en el presente trabajo ha sido más modesto, pues sólo pretendemos efectuar una pequeña aportación a la clarificación de la referida cuestión general, centrándonos en el análisis de un aspecto muy concreto: la valoración de la incidencia de las intervenciones directas de los monarcas en la selección de los regidores de las ciudades con voto en Cortes, y sus efectos desde la perspectiva del fortalecimiento de los vínculos políticos entre la monarquía y los grupos gobernantes de dichas ciudades. 


\section{EL MARCO INSTITUCIONAL:}

\section{LOS AYUNTAMIENTOS CERRADOS DE REGIDORES VITALICIOS}

En el panorama urbano de la Europa bajomedieval las ciudades castellanas pertenecientes al realengo destacaron a partir de mediados del siglo XIV por contarse entre las que disfrutaron de menor margen de autonomía frente a las instancias de poder superiores, y en concreto frente a la monarquía. En efecto, por contraste con lo que había sucedido entre los siglos XI y XIII, cuando la mayor parte de las ciudades castellanas habían tenido reconocida una notable capacidad de autogobierno, desde la segunda mitad del siglo XIII los reyes de Castilla mostraron un progresivo interés por someter a su control las instituciones de gobierno y administración de justicia de sus ciudades, y esta tendencia se reforzó a mediados del siglo XIV, cuando Alfonso XI impuso una profunda reforma de dichas instituciones, que tuvo su pieza clave en la creación del regimiento. A partir de entonces, en efecto, los principales oficios de gobierno en las ciudades pasaron a ejercerse en nombre del rey, y no, como hasta entonces, por delegación de la correspondiente sociedad política local, que, además de quedar anulada como instancia legitimadora del ejercicio del poder en el ámbito local, fue en gran medida privada de su capacidad de intervenir en la selección de sus gobernantes. Y esto porque los regidores que a partir de mediados del siglo XIV gobernaron junto con los oficiales de la justicia la mayor parte de las grandes ciudades castellanas, con la única excepción significativa de Toledo, donde no los hubo hasta $1422^{2}$, tuvieron por encima de todo la condición de oficiales al servicio del monarca, que era el único a quien tenían que rendir cuenta de sus actuaciones.

\footnotetext{
${ }^{2} \mathrm{El}$ caso de Guadalajara es más problemático, ya que tenemos constancia de que en 1405 se llevó a cabo una reforma institucional, que conllevó la creación de ocho oficios de regidores. Pero en las ordenanzas de 1346 ya se habla de 12 hombres buenos que tenían facultad de "ver fazienda del conçejo", denominación muy parecida a la que adoptaron los regidores en otras muchas ciudades durante el siglo XIV. Vid. LóPEZ VILLALBA (1992), p. 67. También se ha cuestionado que hubiese regidores en Soria en la segunda mitad del siglo XIV (ASENJO, 1999a, pp. 507 y ss.) Intentamos rebatir esta tesis, aportando pruebas para demostrar que sí que los hubo desde al menos el reinado de Pedro I, en DIAGo, 2001, pp. 129 y ss.
}

«Anuario de Estudios Medievales», 32/2 (2002), pp. 879-913.- ISSN 0066-5061. 
La introducción de la institución del regimiento no sólo propició, sin embargo, un fortalecimiento de la capacidad de control por parte de la monarquía de los órganos de gobierno de las ciudades, sino que al mismo tiempo puso las bases para la consolidación definitiva de los grupos oligárquicos urbanos, puesto que en la mayor parte de los casos los oficios de regidor terminaron convirtiéndose en oficios de carácter vitalicio, cuando no tuvieron este carácter ya desde el principio. Y, además, con el transcurso del tiempo, se impuso la costumbre de que se pudiesen transmitir de padres a hijos, por lo que progresivamente fueron adquiriendo el carácter de un bien patrimonial, que, ya de forma explícita, pasó a reconocérseles en los siglos XVI y XVII, cuando se pusieron a la venta por la propia monarquía, habitualmente con el derecho adscrito de poderlos ejercer a perpetuidad el comprador y sus sucesores.

De hecho estos dos fenómenos del fortalecimiento del control por la monarquía de los órganos de gobierno de sus ciudades y la consolidación en éstas de grupos oligárquicos, se reforzaron mutuamente, hasta el punto de que pueden ser considerados en última instancia como dos caras de una misma moneda. Pues no cabe duda de que los reyes podían controlar de forma mucho más eficaz a sus ciudades si éstas estaban gobernadas por reducidos grupos oligárquicos, con cuyos miembros pudiesen entablar con más facilidad estrechas relaciones personales, que si lo estaban por grupos muy numerosos y en constante renovación.

En cualquier caso conviene precisar que, aunque la implantación de la institución del regimiento contribuyó sin duda a conferir un cierto carácter uniforme al régimen de gobierno local vigente en los principales núcleos urbanos del reino de Castilla, éste continuó siendo en lo substancial muy heterogéneo. Y esta situación se tradujo en el hecho de que los procedimientos establecidos para la selección de los regidores no fueron los mismos en todas las ciudades, sino que en cada una de ellas adoptaron matices propios.

Para empezar, habría que diferenciar entre ciudades en las que los oficios de regidor tuvieron carácter vitalicio, y ciudades en que estos oficiales se debían renovar todos los años, puesto que en el primer caso los designados o electos necesariamente debían recibir su nombramiento formal del rey, mientras que en el segundo caso no era necesario, y de hecho nunca lo recibían. En el siglo XV las ciudades con voto en Cortes pertenecieron en su 
integridad al primer grupo, es decir, tuvieron regidores vitalicios, aunque en algunas de ellas esta figura institucional se consolidó bastante tarde, como es el caso de la de Murcia, que entre 1325 y 1422 conoció al menos trece cambios en la regulación de la composición del regimiento, en algunos de los cuales se contempló la obligatoriedad de la renovación periódica de los oficiales, incluidos los regidores ${ }^{3}$. Y, en otras nos consta que se llegó a plantear en algún momento el proyecto de sustituir los oficios de regidor vitalicios por otros de renovación anual, como ocurrió en Cuenca en 1465 (JARA, 1999), aunque tales propuestas reformistas acabaron en un rotundo fracaso, porque la resistencia a ponerlas siquiera en marcha fue enorme.

De forma que, en resumidas cuentas, durante el siglo $\mathrm{XV}$, y salvo que en futuras investigaciones se demuestre lo contrario, los regidores de las diecisiete ciudades con voto en Cortes recibieron sus nombramientos directamente del rey, mediante real provisión, con la presentación de la cual podían proceder a tomar posesión en los ayuntamientos de concejo. Pero éste era el único punto en el que el procedimiento de designación de los regidores resultaba coincidente en todas ellas, puesto que, en las etapas previas a la expedición de la provisión de nombramiento, en cada ciudad se seguía un proceso diferente de selección de los candidatos que se habían de proponer al rey.

\section{PROCEDIMIENTOS DE SELECCIÓN DE REGIDORES PREVIOS AL NOMBRAMIENTO REGIO}

En efecto, los regidores vitalicios, a pesar de que formalmente recibían sus nombramientos del rey, tendieron a ser designados en el seno de las correspondientes sociedades políticas locales, limitándose el monarca de turno a confirmar a los candidatos que se le proponían. Y la norma que reguló este proceso de selección previo difirió apreciablemente de unas ciudades a otras.

\footnotetext{
${ }^{3}$ Esta circunstancia puede contribuir a explicar el hecho de que en 1520 una de las principales reivindicaciones de los comuneros murcianos fuese la supresión de los oficios de regidores vitalicios y su sustitución por otros de renovación anual.

«Anuario de Estudios Medievales», 32/2 (2002), pp. 879-913.- ISSN 0066-5061.
} 
En algunas como Toro o Cuenca, los reyes tenían reconocida una cierta capacidad de intervención en este proceso, porque estaba previsto que, cada vez que quedase vacante un oficio, la asamblea concejil designase una terna de candidatos para presentarla al monarca a fin de que entre los tres propuestos escogiese a uno. Pero en el resto, por el contrario, el papel del rey quedaba reducido de hecho al de simple confirmante del candidato que previamente había sido designado por la correspondiente sociedad política local, o algún sector de la misma.

En un pequeño grupo de ciudades, en concreto, el derecho de proponer candidatos al rey para el desempeño del oficio de regidor fue ejercido por las corporaciones de nobleza urbana, conocidas con el nombre de linajes, y no por el ayuntamiento de concejo como principal instancia de gobierno local. Nos consta que este tipo de corporaciones existieron en cinco ciudades con voto en Cortes, todas ellas localizadas en la submeseta norte, que fueron Soria, Segovia, Valladolid, Ávila y Salamanca. Pero sólo en una de estas cinco ciudades, Soria, dichas corporaciones o linajes tuvieron reconocido, con exclusividad y de forma expresa, el derecho a participar activamente en la selección de los regidores. En efecto, allí los miembros del estamento privilegiado hidalgo se distribuían en doce linajes que, a efectos de proveer los seis oficios de regidor del número con que contó la ciudad hasta el año 1543, se agrupaban en parejas de dos, de forma que, cuando un regidor fallecía, el linaje que formaba con él pareja debía reunirse para designar entre sus miembros, mediante votación, un candidato para ocupar el oficio que había quedado vacante, el cual debía ser confirmado por el rey. En las otras cuatro ciudades no tenemos constancia de que los hidalgos que estaban adscritos a cada linaje participasen de una forma igualmente activa, y conforme a unos criterios formalmente tan "democráticos", en el proceso de selección de los candidatos a regidores. Pero, aunque éstos se seleccionasen por otros procedimientos, en principio debía de hacerse de tal forma que en todo momento cada linaje estuviese representado en el ayuntamiento por igual número de regidores. En Valladolid, en concreto, la mitad de los regidores debían pertenecer al linaje de Tovar y la otra mitad al de Reoyo (RUCQUOI, 1987), mientras que en Salamanca, en aplicación de las ordenanzas de Sotos Albos, estos oficios debían repartirse a partes iguales entre los dos linajes de Maldonados y Tejadas (LóPEZ BENITO). En Segovia el panorama era algo más

«Anuario de Estudios Medievales», 32/2 (2002), pp. 879-913.- ISSN 0066-5061. 
complejo, puesto que cuando Alfonso XI creó allí el regimiento dispuso que hubiese quince oficiales, de los cuales cinco deberían ser pecheros, dos en representación de la ciudad y tres en representación de la Tierra, y los otros diez caballeros, debiéndose distribuir estos últimos por mitad entre los dos linajes de Día Sánchez y Fernán García. Pero en la segunda mitad del siglo XV estos criterios de adscripción de los oficios habían dejado de observarse, y de hecho todas las regidurías habían pasado a ser ocupadas por caballeros, sin que importase su pertenencia a uno u otro linaje para poder acceder al ejercicio del oficio (ASENJO, 1986). Y en Ávila, por fin, por indicios podemos presumir que los oficios de regidor se repartían por mitad entre los linajes de San Vicente y San Juan, aunque no disponemos de pruebas de que éstos llegasen en algún momento a intervenir activamente en su selección, al modo como lo hacían en Soria ${ }^{4}$.

En conclusión, por tanto, dentro del grupo de las ciudades con voto en Cortes Soria destacó en el siglo XV como caso excepcional, por ser la única en que el procedimiento ordinario de selección de los regidores contemplaba la activa participación de la gran mayoría de los miembros del estamento hidalgo, los que estaban adscritos a linajes, mediante el ejercicio del derecho de voto. Pero, en aras a la precisión, se ha de hacer constar que esta peculiaridad de su régimen constitucional la compartía con otros varios núcleos urbanos de la submeseta norte de cierta relevancia como eran Medina del Campo y Olmedo, y, con ciertas reservas, también Arévalo y Ciudad Rodrigo (DIAGo, 1997). Y, por otra parte, el hecho de que en las ciudades de Valladolid, Salamanca, Segovia y Ávila, se diesen otras formas de vinculación de los regimientos a los linajes, también demuestra que en ellas el control de los oficios de gobierno local por las corporaciones de nobleza urbana fue, al menos en origen, bastante fuerte, y así fue formalmente admitido por la propia monarquía.

A diferencia del anterior grupo de ciudades, en otras se llegaron a poner en práctica en alguna ocasión procedimientos de selección de los regidores que permitían la activa participación de un amplio espectro de la

${ }^{4}$ En la ordenanza que aprobó el concejo de Ávila en 1515 para regular el proceso de elección de los procuradores a Cortes se dispuso que se hiciese por sorteo entre los regidores, echando en un cántaro papeletas con los nombres de los regidores del linaje de San Juan, y en otro con los nombres de los regidores del linaje de San Vicente. Vid. DIAGO, 1993b.

«Anuario de Estudios Medievales», 32/2 (2002), pp. 879-913.- ISSN 0066-5061. 
correspondiente sociedad política local, y no sólo de los privilegiados. Un ejemplo notable nos lo proporciona Madrid, donde por cédula de Juan I del año 1381 se dispuso reducir el número de oficios de regidor a seis, y se instauró un procedimiento electivo en el que se contemplaba la participación de escuderos, caballeros de alarde y pecheros, reunidos todos ellos en una misma asamblea, teniendo derecho a poder resultar elegidos tanto caballeros como pecheros (LOSA CONTRERAS, p. 283). Pero, a juzgar por los datos de que hoy por hoy disponemos, parece que este tipo de procedimiento tuvo un carácter marcadamente excepcional, y no llegó a consolidarse en ninguna ciudad. De forma que, dejando a un lado los casos de las ciudades que contaban con corporaciones de nobleza urbana bien estructuradas, el órgano principal que en las ciudades castellanas con voto en Cortes decidió sobre la selección de los candidatos para cubrir oficios de regidor vacantes fue el ayuntamiento de concejo, constituido en la mayor parte de los casos sólo por oficiales de la justicia y regidores.

En la práctica, sin embargo, durante el siglo XV los procedimientos ordinarios previstos en las distintas ciudades para seleccionar a los regidores no fueron siempre respetados, porque poco a poco se fue imponiendo el procedimiento de las transmisiones de los oficios entre particulares, generalmente parientes, por virtud de renuncia, en vida o para después de la muerte. $\mathrm{Y}$ estas operaciones se llevaron a cabo en todas las ciudades sin excepción, aunque, por supuesto, la resistencia que ofrecieron las autoridades concejiles, u otras instancias de las sociedades políticas locales, a admitir su validez varió apreciablemente en intensidad de unas ciudades a otras.

En concreto, esta resistencia fue bastante grande en ciudades como Soria, puesto que al estar agrupados por parejas los linajes para la provisión de un único regimiento, si se admitía una renuncia se interrumpía el turno rotatorio y se privaba por consiguiente a un linaje de su derecho a participar en la designación de regidor por un período de tiempo que podía llegar a ser muy prolongado. Y por ello, todavía a principios del siglo XVI, cada vez que en Soria se producía una renuncia de un oficio de regidor de padre a hijo tenía lugar una rápida reacción de los terceros perjudicados, que no dudaban en recurrir por vía judicial hasta el propio Consejo Real, aunque siempre con escaso éxito (DIAGO, 1993a, p. 276).

«Anuario de Estudios Medievales», 32/2 (2002), pp. 879-913.- ISSN 0066-5061. 
En otras ciudades, sin embargo, los beneficiarios de estas renuncias tropezaron con muchos menos obstáculos a la hora de ser admitidos como regidores por el resto de los miembros del ayuntamiento, aunque al parecer no en todas se realizaron estas operaciones con similar frecuencia. En concreto, en un estudio comparativo sobre las ciudades de Burgos y Cuenca los profesores Sánchez Benito y Guerrero Navarrete constatan que, mientras que en la primera ciudad fueron muy frecuentes las transmisiones de oficios de padres a hijos, en la segunda éstas resultaron mucho más raras, debido fundamentalmente a que el grupo oligárquico conquense alcanzó en los siglos bajomedievales un muy menor grado de desarrollo y apenas pudo desarrollar la capacidad de controlar su propia composición, debiendo admitir constantes intervenciones del rey en la designación de los regidores (SÁNCHEZ BENITO y GuerRero NAVARRETE, 1997). Pero este punto de vista ha sido en parte matizado después por Jara Fuente, quien ha demostrado que bastantes linajes conquenses demostraron notable capacidad para patrimonializar el oficio de regidor en el XV, y las transmisiones de padres a hijos se llevaron a efecto sin tener que hacer frente a ninguna resistencia importante (JARA FUENTE, 2000, pp. 109 y ss, y 123 y ss).

En cualquier caso, tanto si se aplicaba el procedimiento ordinario de selección de regidores, como si se seguía este irregular procedimiento de las renuncias, al rey le quedaba en todos los casos escaso margen para poder imponer a sus propios candidatos en los regimientos de sus principales ciudades, ya que, a pesar de que formalmente era el único legitimado para nombrarlos, se limitaba a confirmar a los candidatos que le eran presentados o, a lo sumo, en unas pocas ciudades, a elegir entre una terna.

Ciertamente los monarcas castellanos se reservaron la potestad de autorizar mediante privilegio de merced las transferencias de oficios de regidor de padres a hijos, o en favor de algún otro familiar o extraño ${ }^{5}$. Y este privilegio con frecuencia lo concedieron para recompensar o premiar a los

${ }^{5}$ Por ejemplo en 1476 los Reyes Católicos hicieron merced a su maestresala Gonzalo de Ávila, regidor de Ávila, en premio a sus servicios, para que, bien en vida o bien tras su muerte, pudiese renunciar su oficio en favor de su hijo Andrés Vázquez, u otra persona que él desease. Vid. José Luis MARTÍN RODRÍGUEZ, Documentación Medieval Abulense en el Registro General del Sello, vol. I, Ávila, 1995, Doc. 41. Vitoria, 11-VI-1476. Esta merced fue reiterada en 1478, autorizándole a renunciar no sólo el oficio de regidor sino también el de alférez. Íbid. Doc. $\mathrm{n}^{\mathrm{0}}$. 69. Sevilla, 28-I-1478.

«Anuario de Estudios Medievales», 32/2 (2002), pp. 879-913.- ISSN 0066-5061. 
procuradores que actuaron en determinadas reuniones de Cortes ${ }^{6}$. Pero, al mismo tiempo, también confirmaron muchas operaciones de traspaso de oficios de regidor que no nos consta que se encontrasen amparadas por ningún privilegio previo. Lo cual demuestra que la utilidad práctica de estos privilegios que autorizaban la renuncia de oficios era bastante limitada, aunque, por supuesto, no nula, puesto que siempre resultaba mucho más difícil resistirse a admitir la validez de una renuncia cuando estaba amparada por un privilegio de carácter explícito que cuando no lo estaba.

En cualquier caso, aunque los reyes apenas interviniesen en el proceso de selección de los regidores numerarios de sus ciudades, no dejaban de mantener un pleno control sobre ellos, puesto que eran oficiales a su servicio, $\mathrm{y}$, por consiguiente, podían llegar a destituirlos si no cumplían adecuadamente con sus funciones. Las destituciones de regidores por los reyes fueron muy poco frecuentes, pero en determinadas circunstancias, y por motivos eminentemente políticos, sí se llegaron a decretar en un número importante. En concreto así ocurrió a comienzos del reinado de los Reyes Católicos, cuando estos monarcas destituyeron a varios oficiales que habían tomado el partido del rey de Portugal y de la princesa Juana, llamada la Beltraneja, aunque, más adelante, algunas de estas destituciones fueron revocadas, porque se optó por dar prioridad al objetivo de conseguir la reconciliación con los vencidos ${ }^{7}$. Y, más adelante, se volvió a producir una situación semejante tras

\footnotetext{
${ }^{6}$ Aunque los ejemplos son numerosos, citaremos dos tomados de la ciudad de Cuenca. En concreto Fernando de Valdés, por acudir como procurador a las Cortes de Valladolid de 1506 , obtuvo merced de poder renunciar su oficio de regidor en cualquier persona, aunque, después de efectuar la renuncia, no viviese los 20 días que la ley disponía. Esta merced le fue confirmada por real provisión de Valladolid 16-III-1518, y en uso de la misma renunció el oficio en 1520 en su hijo Andrés de Valdés. Consta por libros de actas del concejo de Cuenca, sesión de 29-III-1520. Otro ejemplo interesante, también tomado de Cuenca, nos lo proporciona el caso de Juan de Chinchilla, quien fue elegido procurador a Cortes para jurar al príncipe Carlos. Al parecer él no acudió personalmente a la reunión de Cortes, sino que "por servicio de la reina dio su voto a Rodrigo Manrique, también regidor de Cuenca, que fue quien acudió a las Cortes y juró al príncipe Carlos, a la vez que acató a Fernando el Católico como gobernador. Por ello a Juan de Chinchilla en recompensa se le dio licencia para renunciar el oficio de regidor, y en 1513 lo hizo en favor de su hijo Gregorio de Chinchilla. AGS, RGS, V- 1513.

${ }^{7}$ Por ejemplo en 1475 se concedió a Pedro Núñez de Guzmán el regimiento en León del que se acababa de privar a Enrique de Figueredo, por haber seguido el partido del rey de Portugal. RGS, X 1475, fol. 641. Al año siguiente se le restituyó, no obstante, a este último el oficio, en cumplimiento de un capítulo contenido en los acuerdos con el maestre de Calatrava y el conde de Urueña, su hermano, cuando éstos volvieron a la obediencia de los reyes. RGS, X 1476, fol. 642 y XI 1476, fol. 701 . No sabemos si a raíz de ello Pedro Núñez de Guzmán perdió el regimiento.
}

«Anuario de Estudios Medievales», 32/2 (2002), pp. 879-913.- ISSN 0066-5061. 
la derrota de los comuneros en abril de 1521 , cuando numerosos regidores de diversas ciudades castellanas de la meseta fueron privados de sus oficios en castigo por su participación en la rebelión, y a varios de ellos se les impusieron incluso penas muchos más severas, como la de muerte, que fue llevada a ejecución en varias ocasiones, y la de destierro del reino.

En circunstancias normales, sin embargo, los monarcas apenas decretaron destituciones de regidores, salvo que existiesen razones graves para hacerlo, como por ejemplo la pérdida de la salud mental ${ }^{8}$. Y, sólo en una ocasión sabemos que impusieron un cese colectivo de estos oficiales en una ciudad en concreto. Ocurrió en Madrid en 1490, cuando, como consecuencia de los enfrentamientos que entonces se desataron entre buena parte de los oficiales del concejo y el corregidor Juan Pérez Barradas, los regidores, con la excepción de Diego de Vargas, Gonzalo de Monzón y Francisco de Alcalá, dejaron de asistir a los ayuntamientos. Pues, en respuesta a esta actitud de rebeldía, los reyes ordenaron el cese inmediato de la casi totalidad de los regidores madrileños, privándoles de los honores y emolumentos que por razón de su oficio les correspondían, y sustituyéndoles por otros caballeros en los que tenían depositada mayor confianza. Pero, en honor a la verdad, hay que hacer constar también que esta medida sólo tuvo efectos transitorios, puesto que ya en mayo de 1492 los monarcas dieron nueva orden para que los oficiales depuestos fuesen restituidos en sus oficios (LOSA CONTRERAS, p. 288).

Casos menos espectaculares de ceses colectivos puede, no obstante, que tuviesen lugar en otras ciudades, aunque de momento han pasado desapercibidos para los investigadores. Y a sospecharlo nos invita una noticia inédita encontrada en el Archivo General de Simancas, donde se conserva una carta de poder otorgada en 1501 en nombre de cinco regidores de Cuenca -Pedro de Barrientos, Luis Hurtado de Mendoza, Pedro de Alcalá, Alonso

Sí consta que en 1495 se concedió un regimiento a Pedro Núñez de Guzmán, contino, en lugar de Nuño de Villafañe, fallecido. RGS, III 1495, fol. 79.

${ }^{8}$ Por este motivo destituyeron los Reyes Católicos al regidor madrileño Rodrigo Alfonso de Oviedo en 1476. AGS, RGS, VII 1476, fol. 476.

«Anuario de Estudios Medievales», 32/2 (2002), pp. 879-913.- ISSN 0066-5061. 
Téllez de Cabrera y Fernando de Valdés- para que en su nombre se suplicase de una carta de suspensión de sus oficios?.

\section{LA INTERVENCIÓN DIRECTA DE LA MONARQUÍA EN LA SELECCIÓN DE REGIDORES MEDIANTE LA CREACIÓN DE OFICIOS ACRECENTADOS}

El hecho de que los monarcas castellanos del siglo XV no dispusiesen apenas de margen para intervenir activamente en la selección de los regidores numerarios de sus ciudades no significa, sin embargo, que su capacidad para influir en la composición de los grupos gobernantes de éstas fuese escasa. Por el contrario, en la práctica fue enorme, aunque varió en intensidad de unas ciudades a otras. Y en la mentalidad de la época estaba por ello muy arraigado el convencimiento de que el rey podía nombrar regidores en sus ciudades a las personas a las que él desease, por lo cual con relativa frecuencia los particulares le cursaron peticiones para que lo hiciese con determinados individuos por los que deseaban interceder. $\mathrm{Y}$ entre quienes así procedieron figuraron personas de gran relieve como, por ejemplo, la propia reina María de Aragón, esposa de Alfonso el Magnánimo, quien en 1452 dirigió una solicitud formal a su hermano, el monarca castellano Juan II, para que se concediese un oficio de regidor en Zamora a Pedro García de Zamora, individuo natural de dicha ciudad, quien había servido como criado a su hermana la infanta Catalina, y también le había prestado a ella misma múltiples y señalados servicios ${ }^{10}$.

$\mathrm{Y}$, sin duda alguna, este convencimiento estaba justificado, porque en el transcurso del siglo XV los monarcas castellanos efectuaron numerosos nombramientos directos de regidores, para lo cual recurrieron de forma

\footnotetext{
${ }^{9}$ AGS, Cámara-Pueblos, leg. 7, fol. 42. Carta de poder otorgada en Cuenca, 3-V-1501. En otro documento de ese mismo año el teniente de corregidor de Cuenca informó que varios regidores habían sido suspendidos de sus oficios por no haber querido ir a visitar los términos de la ciudad con el corregidor Francisco de Bazán. Íbid. leg. 7, fol. 47, Cuenca 18-V-1501.

${ }^{10} \mathrm{ACA}, \mathrm{C}$, reg. 3280-80, Barcelona 7-III-1452. Además de a su hermano Juan II, la reina María dirigió entonces cartas sobre este mismo asunto al relator Fernando Díaz de Toledo, a los regidores de Zamora, y a Alfonso de Estúñiga, quien entonces tenía los oficios de la justicia en Zamora por el rey (fols. 80 y 81 )

«Anuario de Estudios Medievales», 32/2 (2002), pp. 879-913.- ISSN 0066-5061.
} 
sistemática al irregular procedimiento de la creación de oficios "extranumerarios" o "acrecentados", según la terminología de la época. Esta práctica ya se inició en el siglo XIV para compensar a personas del entorno cortesano por los servicios prestados, incluso en ciudades de rango político secundario, como, por ejemplo, Ágreda (DiAGo, 1993, 280-1). Pero en el siglo XV alcanzó mucho mayores proporciones, sobre todo en determinadas ciudades con voto en Cortes, en las que tuvo lugar entonces un proceso de incremento descontrolado del número de oficios de regidor.

En concreto fueron Juan II y Enrique IV los monarcas que más contribuyeron a este incremento, mientras que los Reyes Católicos, por el contrario, se esforzaron por poner freno a la práctica de creación de oficios acrecentados, a la vez que amortizaron muchos de los creados por sus antecesores, conforme iban quedando vacantes por defunción de sus titulares. Pero ni siquiera ellos actuaron de forma plenamente consecuente en la rigurosa aplicación de esta política, y de vez en cuando también crearon oficios acrecentados para premiar a algunos de sus mas fieles servidores ${ }^{11}$, al igual que hizo su nieto Carlos I nada más acceder al trono ${ }^{12}$.

Las ciudades en que tenemos constancia que se creó mayor número de nuevos oficios de regidor durante los reinados de Juan II y Enrique IV fueron aquéllas de la mitad meridional del reino en las que la vigencia del fuero de Toledo venía confiriendo tradicionalmente a la monarquía una mayor capacidad de intervención en las instituciones de gobierno local. Y así, en la propia ciudad de Toledo, en donde la institución del regimiento no se implantó hasta el año 1422, se pasó de los 16 regidores que en aquel momento designó Juan II a los 52 que se llegaron a contabilizar durante el reinado de Enrique IV. Mientras que en Córdoba, ciudad repoblada a mediados del siglo XIII "a fuero de Toledo", se produjo un incremento todavía más espectacular, puesto que a comienzos del reinado de los Reyes Católicos se contabilizaban allí 89 oficios de regidor acrecentado, además de los 24 oficios "del número antiguo"

\footnotetext{
${ }^{11}$ Sobre la provisión de regimientos acrecentados en Salamanca por los Reyes Católicos, vid. LÓPEZ BENITO, p. 32. En Soria estos monarcas concedieron un regimiento acrecentado a Juan de Sarabia, según consta en AGS, RGS, VI-1517.

${ }^{12}$ Sobre la resistencia ofrecida en el año 1518 por los seis regidores del número de Soria a admitir como nuevo regidor al comendador Aguilera, quien acababa de recibir merced de Carlos I de un oficio acrecentado. Vid. DIAGO, 1993a, p. 240.

«Anuario de Estudios Medievales», 32/2 (2002), pp. 879-913.- ISSN 0066-5061.
} 
(CABRERA, p. 102). Estos extremos no se alcanzaron en el resto de las ciudades con voto en Cortes, pero en todas ellas se crearon también numerosos oficios acrecentados, que posiblemente superaron en número a los "ordinarios", si bien éste es un punto que habría que clarificar en el caso de varias de ellas, para las que no se dispone de estudios monográficos que hayan abordado el análisis en detalle de esta cuestión.

Según Monsalvo Antón, en el conjunto de los concejos castellanos bajomedievales, tanto realengos como señoriales, los regidores no conformaron un grupo homogéneo por lo que a su origen social y forma de designación se refiere, sino que se distribuyeron en dos grandes grupos, a los que sólo en unas pocas ciudades se añadió un tercero, el de los regidores pecheros ${ }^{13}$. El primero de dichos grupos estaría constituido por los que este autor denomina "regidores locales patricios", seleccionados por la oligarquía patricia de cada ciudad mediante procedimientos de carácter cooptativo entre los miembros de la comunidad política local. Y el segundo, algo menos numeroso, lo formarían los que él llama "regidores foráneos", designados mediante métodos autoritarios, "de arriba hacia abajo", por el rey en los concejos realengos, y por el señor en los señoriales, los cuales, además, no formaban parte de la sociedad política local, sino que eran forasteros.

Esta neta distinción entre ambos tipos de regidores nos parece, sin embargo, muy cuestionable, porque en prácticamente ninguna ciudad el ordenamiento constitucional vigente contemplaba la posibilidad de que unos regidores pudiesen ser designados por un procedimiento de carácter "autoritario" y otros por uno de carácter "cooptativo". Por el contrario, dicho ordenamiento preveía en cada ciudad un mismo procedimiento para la elección de todos los regidores, aunque en la práctica no siempre se aplicaba, porque con cada vez más frecuencia se admitían las renuncias de oficios, por un lado, o los monarcas imponían la aceptación de nuevos regidores que recibían directamente de ellos su nombramiento, por otro.

\footnotetext{
${ }^{13}$ En concreto la figura de los regidores pecheros sólo la hemos constatado en tres ciudades con voto en Cortes: Segovia, Avila y Guadalajara. Pero, además, en el siglo XV en estas tres ciudades dichos oficiales ya habían dejado de reclutarse en el seno del estamento al que teóricamente representaban, es decir, el pechero, y accedían al desempeño de su oficio por las mismas vías que los regidores hidalgos. También nos consta que en algún momento en ciudades como Madrid los pecheros tuvieron derecho a poder ser elegidos regidores, aunque no se les asignó ningún cupo.
}

«Anuario de Estudios Medievales», 32/2 (2002), pp. 879-913.- ISSN 0066-5061. 
Estos últimos regidores eran los llamados "acrecentados", pero, aunque en una primera aproximación podríamos sentirnos tentados a equipararlos con los que Monsalvo llama regidores "foráneos", no consideramos justificada tal equiparación por varias razones. Y, entre ellas, desde nuestro punto de vista, la principal radica en que sólo se diferenciaban del resto de regidores en virtud del procedimiento por el que habían sido designados, y no por su diferente grado de vinculación con la sociedad política local.

Ciertamente muchos individuos que en origen mantenían escasos vínculos con las ciudades en donde llegaron a ejercer el oficio de regidor accedieron a su desempeño gracias a que el monarca de turno les hizo merced de un regimiento acrecentado. Pero no siempre ocurrió así, puesto que también en otras ocasiones accedieron por otras vías, como, por ejemplo, por haber resultado beneficiarios de la renuncia de un oficio por su anterior titular ${ }^{14}$. Mientras que, en contrapartida, otros muchos individuos procedentes de familias de las oligarquías urbanas llegaron a convertirse en regidores de sus ciudades de origen porque el rey les hizo merced de un regimiento acrecentado.

Por otra parte, muchos de los regidores de origen foráneo que accedieron al desempeño de sus oficios gracias a haber sido directamente nombrados por los reyes se integraron plenamente en la sociedad política de su ciudad de "adopción", consiguiendo incorporarse a su grupo oligárquico, mediante el establecimiento de múltiples vínculos con el resto de familias que formaban el núcleo "autóctono" de dicho grupo, hasta el punto de que muy pronto se les dejó de considerar en sentido estricto "foráneos". Es el caso, por ejemplo, de Gonzalo de Beteta, caballero originario de Ciudad Real ${ }^{15}$, de

\footnotetext{
${ }^{14}$ Por ejemplo el tesorero general de la Hermandad, Alonso Gutiérrez de Madrid, se convirtió en regidor de Madrid, que presumimos que era su ciudad natal, por renuncia que en él efectuó el contador Francisco Núñez de Toledo (AGS, RGS, IX 1494, fol. 54). Al año siguiente renunció, sin embargo, a este oficio de regidor de Madrid en favor de Pedro Suárez Franco (RGS, III 1495, fol. 73), y al mismo tiempo obtuvo un regimiento en Toledo por renuncia de Lorenzo Suárez Franco (RGS, III 1495, fol. 74).

${ }^{15}$ Entre los indicios que prueban la persistencia de la vinculación de la familia de Gonzalo de Beteta con Ciudad Real hay que valorar el hecho de que su hijo, el licenciado Gonzalo López de Beteta, deán de Lugo, dispuso en su testamento la fundación de una capellanía en la iglesia de Santa María de Ciudad Real, para la que nombró como primer capellán a su tío Juan de Hoces, hermano de su madre. AGS, RGS, I-1492, fol. 147. Juan de Hoces fue inquisidor en Ciudad

«Anuario de Estudios Medievales», 32/2 (2002), pp. 879-913.- ISSN 0066-5061.
} 
donde era regidor ${ }^{16}$, quien, tras recibir poco después de 1459 de Enrique IV la tenencia de fortaleza de Soria, pasó a vincularse de forma cada vez más estrecha con la sociedad política de esta ciudad, a la que representó en más de una ocasión como procurador a Cortes, a la vez que consiguió acceder al desempeño en su ayuntamiento de un oficio de regidor, que debió ser acrecentado $^{17}$. Y esta vinculación con Soria quedó reforzada en las siguientes generaciones, de forma que su hijo primogénito Jorge, que le sucedió al frente de la tenencia de la fortaleza tras su muerte en 1484, continuó teniendo fijada en esta ciudad su residencia y ejerció allí el oficio de regidor, al que, a diferencia de su padre, accedió por vía regular, es decir, por nombramiento del linaje al que por turno le correspondía designarlo. Y, en la siguiente generación, también el hijo primogénito de éste, llamado igualmente Jorge, continuó estando presente en el regimiento soriano, en este caso gracias a que su padre renunció en él en vida al oficio.

Ejemplos como los aducidos nos confirman, por tanto, que no hay motivo para establecer una neta diferenciación entre regidores foráneos y regidores locales patricios, como si se tratase de dos tipos de oficios formalmente distintos, con perfiles institucionales bien diferenciados. $\mathrm{Y}$ es que desde el punto de vista institucional la única distinción que contaba era la existente entre los regidores "del número" y los "acrecentados", aunque, a

Real. Vid. Haim BEINART, Records of the Trials of the Spanish Inquisition in Ciudad Real, Jerusalén, 1985, t. IV, pp. 472-3. También tenemos constancia de que la familia continuó poseyendo bienes en Ciudad Real, pues en 1493 el primogénito de Gonzalo de Beteta, Jorge, quien le sucedió en la tenencia de la fortaleza de Soria, solicitó que se le amparase en la posesión de unas casas, censos y viñas, que le pertenecían en aquella capital manchega. AGS, RGS, VIII1493, fol. 37. También se confirma que el comendador Gonzalo de Beteta era originario de Ciudad Real en AChV, RE, leg. 97, III-1496.

${ }^{16}$ Según documento incompleto conservado en AGS, EMR, Mercedes y Privilegios, 43-43, Enrique IV concedió a Gonzalo de Beteta, maestresala, alcaide del castillo de Soria y regidor de Ciudad Real, por haber acudido a una reunión de Cortes como procurador por Soria, la merced de que pudiese traspasar a sus sucesores el oficio del regimiento de Ciudad Real.

${ }^{17} \mathrm{Hay}$ que diferenciar, no obstante, al Gonzalo de Beteta que fue regidor de Soria y Ciudad Real, y procurador a Cortes por Soria, además de comendador de la Orden de Santiago y maestresala de los reyes, del individuo homónimo que fue procurador a Cortes por Cuenca en el reinado de Enrique IV. LORENZO CADARSO, no obstante, los confunde cuando afirma que el de Cuenca, a quien atribuye la condición de converso, fue embajador en Roma, pues ha quedado suficientemente demostrado que éste fue el regidor de Soria. Vid. Florentino ZaMORA LUCAS, Gonzalo de Beteta, embajador en Roma, "Celtiberia", 7 (1957), pp. 129-32. Y José Manuel NIETO SORIA, La nación española de Roma y la embajada del comendador santiaguista Gonzalo de Beteta (1484), “AEM", 28 (1998), pp. 109-121.

«Anuario de Estudios Medievales», 32/2 (2002), pp. 879-913.- ISSN 0066-5061. 
efectos prácticos, ni siquiera ésta tenía apenas consecuencias, salvo en el momento en que fallecía el titular del oficio, puesto que, si se trataba de uno acrecentado, se podía exigir su amortización.

\section{PREDOMINIO DE LOS INDIVIDUOS VINCULADOS A LA MONARQUÍA EN LOS REGIMIENTOS DE LAS PRINCIPALES CIUDADES CASTELLANAS DURANTE EL SIGLO XV}

Los numerosos nombramientos de regidores acrecentados efectuados por los monarcas castellanos durante el siglo XV favorecieron, sin duda, que en los órganos de gobierno de las principales ciudades del reino proliferasen entonces las personas que mantenían una estrecha vinculación personal con la monarquía, traducida en el desempeño de muy diversos oficios de gobierno y administración, además de otros de carácter estrictamente cortesano. Pero conviene precisar que no sólo los regidores acrecentados respondieron a este perfil. También lo hicieron muchos otros individuos que ocuparon oficios de los llamados del "número antiguo", y que no habían sido seleccionados en la mayor parte de los casos directamente por el rey, sino que habían accedido al regimiento por las vías habituales contempladas en las constituciones políticas locales, o, con cada vez más frecuencia, porque alguien, por regla general un pariente próximo, les había traspasado el oficio.

Esta constatación nos confirma, por tanto, que durante el siglo XV la monarquía, que conscientemente trató de reforzar su capacidad de control sobre los órganos de gobierno de sus principales ciudades mediante la promoción de un "partido realista", constituido por personas de su confianza y de probada fidelidad, puso en práctica una doble estrategia para alcanzar este objetivo. Y así, por un lado, creó en ellas numerosos oficios acrecentados con los que trató de premiar a sus servidores más fieles. Pero, por otro lado, también se esforzó por ganarse la confianza de las familias que previamente habían conseguido hacerse con el control de los resortes del poder en cada ciudad, y constituían, por así decirlo, el "núcleo duro" de su oligarquía, mediante el reclutamiento en su seno de muchos de sus servidores, a los que encargó del desempeño de multitud de oficios en los órganos de gobierno y administración, tanto central como territorial y local. Por lo cual, si tenemos 
en cuenta este hecho, entendemos que conviene matizar el punto de vista de la profesora Asenjo González sobre la coexistencia de tres grandes grupos en las oligarquías urbanas de la Castilla del siglo XV, constituidos respectivamente por familias autóctonas, familias de la administración de la monarquía y miembros de la alta nobleza (ASENJO, 1999b). Puesto que, en efecto, la distinción entre "familias autóctonas" y "familias de la administración de la monarquía" resulta algo forzada, ya que en el seno de las primeras los monarcas castellanos del siglo XV reclutaron a un elevado número de sus servidores, que desempeñaron muy diversas funciones en su aparato administrativo y judicial, además de en la propia Corte. Pero, por otro lado, entendemos que dicha distinción resulta útil para llamar la atención sobre el fenómeno de la constante renovación de los grupos oligárquicos de las grandes ciudades castellanas en el transcurso del siglo XV por efecto de la incorporación de familias foráneas, que debían su encumbramiento al favor de la monarquía, al servicio de la cual trabajaban en sus principales órganos de gobierno y administración.

En cualquier caso, no debemos olvidar que la relación de estrecha vinculación que a lo largo del siglo XV mantuvieron con la monarquía las familias que constituían el núcleo "autóctono" de los grupos oligárquicos de las principales ciudades castellanas se fundamentó sobre unas bases de recíproco interés $\mathrm{y}$, por tanto, se trató sistemáticamente de potenciar por ambas partes. Y, en este contexto, se ha de explicar la práctica del envío a la Corte por parte de estas familias de algunos de sus miembros varones, cuando todavía eran niños o adolescentes, para que allí sirviesen a los reyes, príncipes o infantes como pajes o donceles, y al mismo tiempo se educasen y entrasen en contacto con personas que en el futuro pudiesen contribuir a su promoción.

Muchos regidores de las principales ciudades realengas de la Castilla del siglo XV nos consta, en efecto, que sirvieron en las primeras etapas de su vida pública como pajes o donceles en la Corte. Y, en etapas más avanzadas de su trayectoria vital, bastantes de ellos continuaron vinculados al mundo cortesano gracias a haber entrado a formar parte del selecto grupo de los "continos" de los reyes, o porque fueron seleccionados para el desempeño de oficios cortesanos. Hubo, en efecto, entre los regidores de las ciudades castellanas con voto en Cortes durante el siglo XV varios maestresalas de los 
reyes $^{18}$ o de algún príncipe o infante ${ }^{19}$, aposentadores ${ }^{20}$, despenseros ${ }^{21}$, veedores de la despensa ${ }^{22}$, caballerizos ${ }^{23}$, ayos de infantes ${ }^{24}$, y algunos que prestaron servicios profesionales de carácter más específico, como, por ejemplo, los de la medicina ${ }^{25}$. Pero no hay que descartar que en muchos casos estos cargos tuviesen simple carácter honorífico y no conllevasen la obligación del desempeño de unas funciones concretas en la Corte.

Mucha más relevancia práctica que los oficios cortesanos tuvieron, sin embargo, los de gobierno y administración en los órganos centrales del reino, donde la presencia de regidores de las principales ciudades castellanas fue también durante el siglo XV masiva. En concreto, proliferaron en el ramo de la administración hacendística, donde desempeñaron oficios como los de contadores mayores, tesoreros y recaudadores mayores de rentas, que no vamos a entrar a identificar porque habría de resultar en exceso tedioso, y los nombres de varios de ellos irán siendo desgranados a lo largo de nuestra exposición. También estuvieron muy presentes en otros ramos de la administración central, donde algunos de ellos lograron alcanzar posiciones de enorme influencia, como es el caso, por ejemplo, del regidor toledano Fernando Álvarez de Toledo, secretario de los Reyes Católicos. Y, por fin, acapararon una gran parte de los oficios por medio de los que la monarquía

${ }^{18}$ Juan de Torres, regidor de Soria, fue maestresala de Juan II. Gonzalo de Beteta, regidor de Soria y Ciudad Real, lo fue de Enrique IV y de los Reyes Católicos. También lo fue de éstos su hijo Jorge de Beteta, regidor de Soria. Diego de Valderrábano, Juan de Ávila y Gonzalo de Ávila, todos regidores de Âvila, fueron maestresalas de los Reyes Católicos.

${ }^{19}$ Pedro de Luján, regidor de Madrid, fue maestresala de la princesa Isabel, hija mayor de los Reyes Católicos.

${ }^{20}$ Diego de Vargas, regidor de Madrid en 1477, fue aposentador real.

${ }^{21}$ Juan García de Soria, regidor de Valladolid y fiel de la Tierra de Soria, fue despensero mayor de Juan II.

${ }^{22}$ Juan de Labastida, veedor de la casa y despensa de Isabel la Católica, fue nombrado regidor de Guadalajara en 1494. 1478

${ }^{23}$ Pedro de Ribera, caballerizo mayor de la reina, fue nombrado regidor de Valladolid en

${ }^{24}$ Juan de Sepúlveda, regidor de Soria y Sepúlveda, fue ayo del infante Fernando, el futuro emperador, hermano menor de Carlos I. Noticia en AGS, RGS, XII-1508.

${ }^{25}$ Alfonso Cherino, médico de Juan II, fue regidor de Cuenca. Juan Rodríguez de Toledo, médico de los Reyes Católicos, fue regidor de Valladolid.

«Anuario de Estudios Medievales*, 32/2 (2002), pp. 879-913.- ISSN 0066-5061. 
se aseguraba el ejercicio del control sobre los ámbitos territoriales y locales del reino, como era el caso de los de corregidor o justicia mayor, en lo que respecta a gobierno y administración de justicia, y de tenentes de las principales fortalezas del realengo, en lo que toca al control militar.

La presencia masiva en los regimientos de las ciudades castellanas con voto en Cortes de oficiales al servicio de la monarquía destaca como rasgo peculiar de la situación política del reino de Castilla durante el siglo XV. Y desde esta perspectiva el contraste que se advierte con la situación dominante en el siglo XVI es notable, puesto que en dichas ciudades pasaron a predominar en este último siglo los regidores que no se encontraban directamente al servicio de los reyes, y que no dependían de los sueldos y mercedes distribuidos por éstos para el mantenimiento de su posición. Ya algunos investigadores han llamado con anterioridad la atención sobre esta circunstancia, como por ejemplo Thompson, quien considera que uno de los principales rasgos de la política de Carlos I y Felipe II hacia las ciudades con voto en Cortes fue la ausencia de un plan sistemático de implantación en la mismas de regidores fieles o "realistas", mediante la gestión del patronazgo real, porque asignaron prioridad al objetivo de ganarse el favor de los propios procuradores de Cortes para sacar adelante sus proyectos (THOMPSON). Pero habría que avanzar más en la realización de estudios prosopográficos, centrados en el análisis de la evolución del perfil sociopolítico de las oligarquías de las principales ciudades castellanas del siglo XVI, para percibir mejor esta realidad, que hasta ahora los numerosos indicios reunidos sólo nos han permitido entrever ${ }^{26}$.

Durante el siglo XV, por otra parte, la fuerza del "partido realista" en las ciudades con voto en Cortes, y muy en especial en las de la meseta, quedó apreciablemente incrementada como consecuencia de que algunos de sus más significados representantes, todos ellos individuos con notoria influencia en la Corte, y en bastantes casos de origen judeoconverso, lograron acceder al desempeño del oficio de regidor en más de una de estas ciudades. $\mathrm{Y}$ varios parece que lo pudieron hacer incluso de forma simultánea, a pesar

\footnotetext{
${ }^{26} \mathrm{El}$ análisis de un caso concreto, el de Soria, en que se demuestra este contraste en el perfil sociopolítico entre el grupo oligárquico del XV y el del XVI, en DIAGO, 1993c.

«Anuario de Estudios Medievales», 32/2 (2002), pp. 879-913.- ISSN 0066-5061.
} 
de que tal práctica había quedado tajantemente prohibida por las leyes 51 y 55 del Ordenamiento de las Cortes de Zamora de 1432.

Los ejemplos que ilustran esta singular realidad del siglo $\mathrm{XV}$ castellano son relativamente numerosos, y nos limitaremos por ello a continuación a dar cuenta de algunos de los que consideramos más significativos. En primer lugar hay que destacar la figura del contador Alfonso Álvarez de Toledo, procedente de una familia de judíos toledanos, que era primo hermano del relator Fernando Díaz de Toledo, uno de los personajes más influyentes en los órganos de administración central de la monarquía durante el reinado de Juan II. Accedió en primer lugar en 1422 al regimiento de Cuenca, en sustitución de su suegro Juan Fernández de Valera, quien le traspasó en vida el oficio ${ }^{27}$, pero algunos años después, en 1435, aparece ya también identificado en un documento como regidor de su ciudad natal, Toledo (MolÉNAT, p. 572). Y, según Lorenzo Cadarso, lo fue a su vez de Guadalajara desde el año $1421^{28}$, aunque esta última información, que sólo hemos encontrado aportada por este autor, entendemos que habría de ser sometida a rigurosa comprobación. Pero, además, este proceso de acumulación de oficios de regidor en varias de las principales ciudades realengas de Castilla continuó en la siguiente generación de la familia, puesto que su hijo Pedro Núñez de Toledo, también contador mayor, fue regidor de Cuenca, hasta que en 1449 transfirió el oficio a su hermano Juan Álvarez de Toledo (JARA, 2000, pp. 111 y 113), y más adelante lo pasó a ser de Madrid, ciudad en cuyo entorno adquirió los señoríos de Cubas y Griñón ${ }^{29}$. Y, según Lorenzo Cadarso, también lo fue de Guadalajara, aunque, de nuevo, entendemos que esta información hay que tomarla con precaución, en tanto no se profundice más en la reconstrucción de la biografía de este individuo, por cuanto algunos

\footnotetext{
${ }^{27}$ JARA, 2000, p. 114, informa de la transferencia de dicho regimiento, y apunta como hipótesis que Juan Fernández de Valera fuese su suegro. Lo confirma MOLÉNAT, p. 572, indicando que este individuo fue el padre de su primera esposa, Aldonza Fernández.

${ }^{28}$ LORENZO CADARSO, p. 87. Aunque este autor no hace referencia a que fue también regidor de Cuenca y Toledo no cabe duda de que se trata del mismo individuo, ya que sí indica, por ejemplo, que fue contador mayor de Juan II, y el fundador del monasterio cisterciense de Santa María de Montesión, donde fue enterrado. Bastantes noticias sobre la vinculación del contador Alonso Álvarez de Toledo y sus descendientes con este monasterio en AHN, Clero, libro 14.691.

${ }^{29}$ Ocupó el oficio de regidor de Madrid hasta que lo renunció en favor de su yerno D. Juan de Mendoza en 1488. AGS, RGS, VII 1488, fol. 303.
}

«Anuario de Estudios Medievales», 32/2 (2002), pp. 879-913.- ISSN 0066-5061. 
de los datos que este autor proporciona en relación a él resultan tan contradictorios que hay motivos para poner en cuestión su credibilidad. Pues, sobre todo, nos ha llamado la atención que, mientras Layna Serrano sostiene que este Pedro Núñez de Toledo fue en Madrid el dirigente del bando partidario de la reina Isabel la Católica durante la guerra de Sucesión en los años 1475$6^{30}$, Lorenzo Cardarso afirma que estuvo exiliado en Portugal por haber apoyado a Juana la Beltraneja, y que fue indultado en $1477^{31}$.

Pasando a otro ejemplo notorio, recordaremos que Pedro Arias Dávila fue regidor de Segovia y Madrid, al igual que su hijo Diego Arias Dávila, quien a su muerte, en 1476, le sucedió en el desempeño de ambos oficios, aunque por poco tiempo, ya que a los pocos meses falleció él también (RÁBADE, pp. 801-2). Por su parte Francisco Ramírez de Madrid, secretario de los Reyes Católicos y organizador de su artillería, fue nombrado regidor de Toledo el 5 de febrero de 1477, en sustitución de Juan de Córdoba, que había sido destituido en castigo por sus delitos, y diez años más tarde, el 18 de diciembre de 1487, fue recibido como regidor de Madrid (MOLÉnAT, p. 572). $Y$ en estas mismas dos ciudades desempeñó a su vez el oficio de regidor, aunque no de forma simultánea, el tesorero general de la Hermandad, Alonso Gutiérrez de Madrid, quien primero lo fue de Madrid en 1494, por virtud de renuncia que en él efectuó el contador Francisco Núñez de Toledo, y al año siguiente renunció a dicho oficio en favor de Pedro Suárez Franco, obteniendo a cambio uno en Toledo por renuncia de Lorenzo Suárez Franco ${ }^{32}$.

Todos los individuos mencionados hasta ahora desempeñaron oficios de regidor en más de una ciudad con voto en Cortes, pero también se dieron otros casos notorios de destacados servidores de la monarquía que unieron a su condición de regidores de una ciudad con voto en Cortes la de regidores de

\footnotetext{
${ }^{30}$ Francisco LAYNA SERRANO, Historia de Guadalajara y sus Mendozas en los siglos XV y XVI, Aldus, S.A. Madrid, 1942, vol. II, pp. 194 y ss.

${ }^{31}$ Lorenzo CADARSo, p. 87. Sostiene este autor que Pedro Núñez de Toledo, casado con Leonor Arias, fue regidor de Guadalajara desde 1450, fundó el convento de San Bernardo en Guadalajara, y murió hacia 1521. Su hijo Juan Álvarez heredó el regimiento de Guadalajara durante la guerra de Sucesión, hacia 1476. Llama la atención, no obstante, que, aunque indica que de éstos desciende el linaje de los señores de Griñón, no haga ninguna indicación sobre el hecho de que Pedro Núñez de Toledo fue ya señor de Griñón, y además regidor de Madrid, y de Cuenca.

${ }^{32}$ AGS, RGS, IX-1494, fol. 54 y III-1495, fol. 73 y fol. 74. 
otra que no disfrutaba de dicho privilegio, que solía ser su ciudad natal. Éste fue el caso en concreto de dos individuos de origen foráneo que se instalaron en Soria durante el reinado de Enrique IV, y disfrutaron del decidido favor de este monarca, que después les continuaron dispensando sus sucesores los Reyes Católicos, a los que sirvieron en destacadas misiones diplomáticas: Gonzalo de Beteta y Juan de Sepúlveda ${ }^{33}$. Ambos desempeñaron el oficio de regidores en Soria, su ciudad de adopción, gracias a que se crearon para ellos oficios "acrecentados", y al mismo tiempo lo fueron de sus ciudades de origen, es decir, Ciudad Real, en el caso del primero, y Sepúlveda en el caso del segundo ${ }^{34}$.

Y por fin, una última fórmula de acumulación de oficios de gobierno local de varias ciudades con voto en Cortes en manos de un mismo individuo se dio a través del desempeño simultáneo del oficio de regidor en una de ellas y de otro oficio de similar relevancia en otra. En concreto éste fue el caso de Juan García de Soria, tesorero de la reina Catalina de Lancaster, quien compatibilizó el ejercicio del oficio de regidor de Valladolid desde 1409 con el de fiel de la Tierra de Soria, que tenía reconocido derecho de voz y voto en las reuniones del ayuntamiento soriano, aunque este último siempre lo desempeñó a través de lugartenientes, ya que su lugar de residencia habitual fue Valladolid. Y, tras su muerte en 1446, su hijo Luis García de Morales continuó reuniendo en sus manos ambos oficios, aunque también delegó el ejercicio del de fiel de la Tierra de Soria en lugartenientes, que fueron miembros de la familia judeoconversa de los Sanclemente (DIAGO, 1993a, p. 265). Un segundo ejemplo nos lo proporciona la familia Ribadeneira,

\footnotetext{
${ }^{33}$ Noticias sobre la genealogía de Juan de Sepúlveda en RAH, Salazar y Castro, E-12, fols. 92-101. Se le identifica como hijo de Luis González de Sepúlveda, y de Angelina de Contreras, hija de un regidor segoviano. Se confirma que era el hijo de Luis González de Sepúlveda en AGS EMR, Mercedes y Privilegios, leg. 28-2 Segovia, 4-II-1466. Confirmación por Enrique IV del traspaso efectuado por Juan de Sepúlveda de $3.000 \mathrm{mrs}$., de los 15.000 que tenía por juro de heredad, en favor del priorato benedictino de Nuestra Señora la Blanca, o de Mercado, en Soria.

${ }^{34}$ Además de regidor de Sepúlveda, Juan de Sepúlveda desempeñó el oficio de guarda de los pueblos de la Tierra de Sepúlveda. Lo confirma la provisión de Reyes Católicos de Vitoria 14-X1483, publicada por Carlos SÁEZ, Colección Diplomática de Sepúlveda II (1076-1485), Diputación Provincial, Segovia, 1991, doc. 184. En ella se ordena que se le respete la posesión del oficio vitalicio de guarda de la Tierra de Sepúlveda, a pesar de no poderlo ejercer personalmente por estar desempeñando el oficio de corregidor de Guipúzcoa. Que el Juan de Sepúlveda corregidor de Guipúzcoa fue el mismo que desempeñó el oficio de regidor de Soria queda demostrado en AChV, P.C. Alonso Rodríguez, F.C. 1395-2.
} 
originaria de Valladolid y asentada en Toledo en la segunda mitad del siglo $\mathrm{XV}$, puesto que el mariscal Pedro de Ribadeneira fue simultáneamente alcalde mayor de Toledo y regidor de Ávila, oficios ambos en los que, tras su fallecimiento en 1480 , le sucedió su hijo Mateo de Ribadeneira ${ }^{35}$. Y, por fin, como tercer ejemplo, también referente a las ciudades de Toledo y Valladolid, recordaremos el caso del doctor Diego González Franco, contador mayor de cuentas, nacido en Toledo de un judío convertido al cristianismo, quien, además de escribano mayor del concejo de su ciudad natal, llegó a ser regidor de Valladolid, ciudad donde fue recibido en el linaje de Rehoyo en 1448 (MOLÉNAT, p. 577).

Junto a la acumulación de oficios de regidor en varias ciudades por una misma persona, otro factor que contribuyó muy eficazmente al fortalecimiento del "partido realista" en las ciudades con voto en Cortes de la Castilla del siglo XV fue el acaparamiento de estos oficios en varias de ellas por diversos miembros de una misma familia con notoria influencia en la Corte. Ya hemos visto cómo los Álvarez de Toledo estuvieron presentes en los regimientos de las cuatro ciudades realengas de la submeseta sur con voto en Cortes, es decir, Toledo, Cuenca, Guadalajara y Madrid. Por su parte la familia del doctor Juan Díaz de Alcocer, originaria al parecer de Alcalá de Henares, tuvo representación en el regimiento de Valladolid, donde éste accedió al desempeño del oficio en 1494 gracias a una merced que le hicieron los Reyes Católicos en premio a los servicios prestados, y en el de Madrid, a través de su hermano García de Alcocer (RÁBADE, pp. 579-82). A su vez la familia de los Franco, originaria de Toledo, repartió a sus miembros entre los regimientos de Valladolid, donde desempeñó el oficio el doctor Diego González Franco, y de la propia ciudad de Toledo, donde lo hicieron su hermano menor, el tesorero Pedro Franco, y dos de los hijos de éste, Lorenzo Suárez Franco y García Franco (MolÉNAT, pp. 576-8). Y, por fin, por poner

${ }^{35}$ Vid. Carmelo LuIS LÓPEZ, Documentación Medieval Abulense en el Registro General del Sello, vol. II, Ávila, 1993, doc. $n^{\circ} .17$. Toledo, 26-I-1480. Merced a Mateo de Ribadeneira, hijo del mariscal Pedro de Ribadeneira, alcalde mayor de Toledo, del oficio de regidor de Ávila, que le había traspasado su difunto padre. Sobre la presencia de los Ribadeneira en Toledo vid. MOLÉNAT, pp. 583-5. Informa que el mariscal Fernando de Ribadeneira, probablemente originario de Valladolid, fue el primer miembro de la familia en instalarse en Toledo, donde desempeñó el oficio de alcalde mayor de Toledo. Fundó un mayorazgo en favor de su hijo Pedro de Ribadeneira, en el que luego sucedió su nieto Mateo.

«Anuario de Estudios Medievales», 32/2 (2002), pp. 879-913.- ISSN 0066-5061. 
un último ejemplo, recordaremos que mientras el contador Fernán Alfonso de Robles fue regidor de Valladolid, por merced que le hizo el rey en 1414, su hermano Martín González de Robles lo fue de León, la principal ciudad de realengo de la región de origen de la familia.

Otra variante de este mismo fenómeno que también contribuyó al fortalecimiento del "partido realista" en las ciudades con voto en Cortes fue el acaparamiento en algunas de ellas de diversos oficios de regidor por varios miembros de una misma familia estrechamente vinculada con la monarquía. Sin duda el ejemplo más notable desde este punto de vista nos lo proporciona la familia del secretario Fernando Álvarez de Toledo, uno de los individuos más influyentes en la Corte de los Reyes Católicos, puesto que, además de él, otros tres hermanos suyos - Diego López de Toledo, Luis Álvarez de Toledo y Pedro Zapata- desempeñaron oficios de regidores en su ciudad natal de Toledo (MOLÉNAT, pp. 579-83).

No conocemos ningún otro caso semejante de acumulación de tantos oficios de gobierno local en manos de una familia, puesto que la presencia de cuatro hermanos ocupando asientos de regidor en un mismo consistorio representa un hecho verdaderamente insólito, que nos da una buena idea de hasta dónde podía llevar el proceso de arraigo de la concepción patrimonialista del ejercicio del poder iniciado en las ciudades castellanas a partir del momento de la consolidación de la institución del regimiento. Pero casos menos espectaculares se dieron con cierta frecuencia en otras ciudades, $y$, como botón de muestra, recordaremos el de la familia del contador Diego Arias de Ávila, individuo que gozó de notable influencia en la Corte de Enrique IV y fue regidor de Segovia, al igual que un hermano suyo y dos de sus hijos varones, Pedro y Francisco, y su yerno, Gómez González de la Hoz, casado con su única hija, Isabel, mientras que, por su parte, su tercer hijo varón, Juan Arias Dávila, destinado a la carrera eclesiástica, llegó a ser obispo de esa misma ciudad (RÁBADE, pp. 552 y ss y 775-6). Y, por si esto fuera poco, la familia también estableció vínculos matrimoniales con otras familias pertenecientes a los grupos oligárquicos de otras grandes ciudades, puesto que, por ejemplo, Pedro Arias Dávila casó con una hija del regidor de Toledo Alfonso Cota, quien, a su vez, compartió asiento en el regimiento de esta ciudad con su hermano Francisco Cota (MolÉnAT, pp. 574-5). 
Gracias a los numerosos ejemplos aducidos, tomados en su mayoría de las ciudades con voto en Cortes de la meseta, ha podido quedar suficientemente demostrado que en el siglo XV en Castilla los reyes estuvieron en condiciones de ejercer un notable control político de sus principales ciudades a través de un selecto grupo de familias, muchas de ellas de origen judeoconverso, que acapararon una parte importante de los oficios de gobierno en dichas ciudades, y al mismo tiempo desempeñaron numerosos cargos de relevancia en los órganos de administración central y territorial de la propia monarquía. Y por mediación de estas familias no sólo se reforzaron los vínculos políticos entre los monarcas y sus ciudades, sino también los que unían a las diferentes ciudades entre sí.

Este proceso no afectó, sin embargo, a todas las ciudades por igual, sino que fueron las localizadas en la Meseta las que más avanzaron entonces en la línea de reforzar los contactos mutuos, gracias a la función mediadora que asumieron los individuos y familias a los que nos hemos estado refiriendo últimamente, que accedieron a los órganos de gobierno de varias de ellas y al mismo tiempo desempeñaron puestos destacados en los órganos de gobierno y administración central y territorial de la monarquía. Por el contrario las tres ciudades andaluzas con voto en Cortes y la de Murcia apenas se vieron afectadas por este proceso, pudiéndose fácilmente comprobar que los miembros de sus oligarquías mantuvieron una relación muy distante con sus colegas de las ciudades de la meseta. Da la impresión de que unos y otros se integraban en universos políticos distintos, no relacionados entre sí. Y quizás sólo a través del intercambio de corregidores pudo en parte amortiguarse este distanciamiento, aunque de momento ninguna investigación se ha fijado como objetivo tratar de determinar el grado de frecuencia con que durante el siglo $\mathrm{XV}$ se designaron regidores de ciudades de la meseta para desempeñar oficios de corregidores en las ciudades del sur, y viceversa.

En cualquier caso, lo cierto es que este distanciamiento entre unas y otras ciudades quedó plenamente confirmado en los sucesos de los años 1520 y 1521, puesto que fueron sólo las ciudades de la meseta las que se erigieron en protagonistas de la rebelión contra la monarquía representada en la persona de Carlos I que entonces tuvo lugar, mientras que las andaluzas, por el contrario, se mantuvieron en gran medida al margen del proceso, y la ciudad de Murcia, por fin, vivió unos sucesos revolucionarios sui generis, que poca 
relación guardaron con los que tuvieron lugar en el resto de ciudades castellanas.

\section{CONCLUSIÓN}

Aunque queda todavía mucho por aclarar sobre la procedencia social de los oficiales que gobernaron las ciudades castellanas con voto en Cortes durante el siglo $\mathrm{XV}$, las informaciones de las que hoy por hoy disponemos resultan suficientes para poder concluir que un rasgo común a un gran número de ellos fue su condición de individuos al servicio de la monarquía, que con frecuencia desempeñaron otros destacados oficios en sus aparatos de gobierno y administración, tanto central como territorial y local. Y esta circunstancia por fuerza debió tener como consecuencia que todos ellos permaneciesen ausentes durante largas temporadas de las ciudades donde debían ejercer el oficio de regidor, que con bastante frecuencia no fueron sus ciudades de origen, y en algunos casos ni siquiera ciudades con las que les uniese un fuerte vínculo, por haber fijado allí su residencia y la de su familia ${ }^{36}$.

En efecto, hemos podido comprobar que durante el siglo XV muchos individuos llegaron a desempeñar el oficio de regidor en ciudades distintas de la suya de nacimiento, y algunos consiguieron incluso hacerlo en más de una. Y esta práctica, basada en el principio de la movilidad geográfica, debió contribuir de forma decisiva a moderar la tendencia al hermetismo que, sin duda, por mera inercia trataría de imponerse entre los grupos oligárquicos de las grandes ciudades castellanas que se gobernaban por regidores vitalicios, al tiempo que aseguraría a la monarquía una mayor capacidad de influencia sobre los órganos de gobierno de estas mismas ciudades. Pues entendemos que estos individuos y familias más proclives a la movilidad podían ser más

\footnotetext{
${ }^{36}$ Creemos que éste pudo ser el caso del contador Juan Velázquez de Cuéllar, en relación a Ávila, ciudad de la que fue nombrado regidor en marzo de 1510 por virtud de renuncia que en él efectuó de su oficio Nuño González de Aguila. Entonces Juan Velázquez de Cuéllar, además de desempeñar las funciones de contador mayor en la Corte, era tenente de la fortaleza realenga de Arévalo, y controlaba el oficio de corregidor de Soria, por lo que presumimos que en Ávila fue ante todo un oficial absentista. Vid. M. Diago HernaNDo, Los Velázquez de Cuéllar, tenentes de Arévalo, en el horizonte político castellano a fines de la Edad Media, "Cuadernos Abulenses", 16 (1991), pp. 11-40.
}

*Anuario de Estudios Medievales*, 32/2 (2002), pp. 879-913.- ISSN 0066-5061. 
fácilmente utilizados por la monarquía como eficaces agentes para vencer las resistencias "localistas" al cumplimiento de sus disposiciones más "impopulares".

Al mismo tiempo consideramos, no obstante, que el funcionamiento de todo el sistema debió estar basado en el respeto escrupuloso de los principios de fidelidad sobre los que se sustentaban las relaciones vasalláticas, puesto que, como ya hemos adelantado, una consecuencia importante del régimen de reclutamiento de los regidores de las ciudades castellanas vigente durante el siglo XV fue la generalización del absentismo de estos oficiales "por razones de trabajo", es decir porque se encontraban sirviendo a la monarquía en otros lugares del reino o de fuera de é ${ }^{37}$. Y, por consiguiente, existen razones suficientes para presumir que las tareas de gobierno cotidiano de las ciudades fuesen asumidas en su mayor parte por individuos que desempeñasen oficios de carácter subalterno y formasen parte de las clientelas de los regidores ausentes, en los cuales éstos tendrían depositada absoluta confianza, o tal vez por otros regidores de menor relieve político sobre los que los ausentes pudiesen ejercer su influencia desde la distancia. En cualquier caso estas hipótesis habría que comprobarlas por medio de trabajos monográficos centrados en el análisis del funcionamiento cotidiano de las instituciones concejiles, que no siempre resultan de fácil realización por falta de fuentes de información, y, más en concreto, por no haberse conservado los libros de actas concejiles. Pero en caso de no ser factibles tales estudios, también pueden arrojar cierta luz sobre este asunto los trabajos de prosopografía orientados a mejorar nuestro conocimiento de los vínculos de afinidad política que unieron a determinados miembros de grupos oligárquicos de diferentes ciudades entre sí.

En efecto, por medio de estos trabajos se pueden llegar a percibir fenómenos muy reveladores, que demuestran que la red de relaciones

\footnotetext{
${ }^{37}$ Como ejemplo ilustrativo de prolongado absentismo citaremos el caso del regidor de Soria Gonzalo de Beteta, quien a pesar de haber sido designado procurador por esta ciudad para asistir a las Cortes de Toledo de 1480, sabemos que ya desde julio de este año se encontraba en Roma actuando como embajador. Y el desempeño de esta misión absorbió la práctica totalidad de su tiempo hasta su muerte en la propia ciudad de Roma en el año 1484, puesto que, aunque en el intermedio consta que realizó algún viaje a la Península, fue para inmediatamente regresar a Roma. De forma que durante todos estos años materialmente nu pudo pasar ni un solo día en Soria o en Ciudad Real, las dos ciudades donde en teoría desempeñaba el oficio de regidor.
}

«Anuario de Estudios Medievales», 32/2 (2002), pp. 879-913.- ISSN 0066-5061. 
personales sobre la que se fundamentaba el ejercicio del poder en el realengo castellano a fines de la Edad Media era enormemente intricada, y por ello posibilitaba que, a pesar del absentismo de los oficiales de mayor rango, éstos tuviesen asegurado un efectivo control de los órganos de gobierno local. Y a título meramente ilustrativo recordaremos un ejemplo en concreto, el de la relación que unió durante el reinado de los Reyes Católicos al regidor soriano Juan Morales con el contador mayor Juan Velázquez de Cuéllar, quien sucedió a su padre, el licenciado Gutierre Velázquez de Cuéllar, en el oficio de corregidor de Soria tras su muerte hacia el año 1492 Este influyente cortesano, que continuó controlando el corregimiento soriano hasta después de la muerte de Fernando el Católico, fue, por supuesto, un oficial absentista, que delegó en miembros de su clientela la tarea de gobernar e impartir justicia en Soria y su Tierra. A pesar de ello su autoridad en este ámbito jurisdiccional fue notoria, y quedó reforzada gracias a la estrecha alianza que estableció con algunos de los regidores más influyentes de la ciudad del Duero, en particular con Juan Morales, quien, según se denunció más tarde, amparado en su relación de amistad con el titular del corregimiento, cometió todo tipo de abusos, atreviéndose incluso a dejar de pagar sus deudas a sus acreedores. Pues bien, no deja de resultar sintomático que este mismo Juan Morales, que era "contino" de los reyes y fue premiado por ellos con diversas mercedes ${ }^{38}$, fuese designado en varias ocasiones para desempeñar el oficio de corregidor de Arévalo, la villa abulense con la que los Velázquez de Cuéllar mantenían una estrecha vinculación desde que asumieron la custodia de la reina loca Doña Isabel de Portugal, madre de Isabel la Católica. El propio contador Juan Velázquez de Cuéllar tuvo a su cargo durante muchos años la tenencia de la fortaleza de esta villa, coincidiendo con la presencia allí de Juan Morales como corregidor, y llegó a erigirse en la máxima autoridad del lugar. Y así se puso bien de manifiesto cuando en el otoño de 1516 encabezó la rebelión de esta población contra Carlos I, a raíz de haber concedido éste el lugar en

\footnotetext{
${ }^{38} \mathrm{Hay}$ que destacar que le nombraron tenente de la fortaleza de Castil de Tierra, y le hicieron merced de las cáñamas que pagaban los doce escribanos del número de Soria. Vid. DIAGO, 1993a, p. 204

«Anuario de Estudios Medievales», 32/2 (2002), pp. 879-913.- ISSN 0066-5061.
} 
señorío a la viuda de Fernando el Católico, Germana de Foix, en una arriesgada apuesta que precipitó su caída en desgracia ${ }^{39}$.

Entendemos, por tanto, que la presencia simultánea de estos dos individuos en el desempeño de destacados oficios de gobierno local en Arévalo y Soria debió contribuir a reforzar notablemente su capacidad de ejercicio del poder en ambos lugares, y a mitigar el alcance de los inconvenientes que de su absentismo se pudiesen derivar. Y, desde esta perspectiva, no dejamos de considerar sintomático que precisamente a partir del momento en que la estrella política de Juan Velázquez de Cuéllar comenzó a declinar, debido a la fuerte oposición que ofreció al nuevo monarca Carlos I, las dificultades comenzasen a multiplicarse para Juan Morales en Soria, hasta el punto de que llegó a ser desterrado de esta ciudad en castigo a un grave delito del que se le encontró culpable (DiAGO, 1993a, pp. 238-43).

${ }^{39}$ Vid. Eduardo RuIz AYÚCAR, El alcalde Ronquillo. Su época. Su falsa leyenda negra, Ávila, 1958, pp. 50-6.

«Anuario de Estudios Medievales», 32/2 (2002), pp. 879-913.- ISSN 0066-5061. 


\section{BIBLIOGRAFÍA}

ARAnda PÉRez, F.J. (1999): Poder y poderes en la ciudad de Toledo. Gobierno, sociedad y oligarquías urbanas en la Edad Moderna, Cuenca, Universidad de Castilla-La Mancha.

ASENJo GonZÁlez, María (1986): Segovia. La ciudad y su Tierra a fines del Medievo, Segovia.

ASENJO GONZÁLEZ, María (1999a): Espacio y sociedad en la Soria medieval. Siglos $X I I I-X V$, Soria, Diputación Provincial.

ASENJo GoNZÁleZ, María (1999b): Las ciudades, en José Manuel NiETo SoRIA (Dir.), Orígenes de la monarquía hispánica: Propaganda y legitimación (ca. 1400-1520), Madrid, Dykinson, pp. 105-140.

BONACHÍA HERNANDO, Juan Antonio (1978): El concejo de Burgos en la Baja Edad Media (1345-1426), Valladolid, Universidad.

BONACHÍA HERNANDO, Juan Antonio y MARTín CEA, Juan Carlos (1998): Oligarquias y poderes concejiles en la España bajomedieval: balance y perspectivas, "Revista d'Historia Medieval", 9, pp. 17-39.

CABAÑAS GonZÁleZ, María Dolores (1982): La reforma municipal de Fernando de Antequera en Cuenca, en Cuenca y su territorio en la Edad Media, Barcelona, CSIC, 1982, pp. 381-97.

CABRERA SÁNCHEZ, Margarita (1998): Nobleza, oligarquía y poder en Córdoba al final de la Edad Media, Córdoba, Universidad.

CORIA COLINO, Ildefonso (1995): Intervención regia en el ámbito municipal. El concejo de Murcia (1252-1369), Murcia.

DiAgo HeRnANDo, Máximo (1993a): Estructuras de poder en Soria a fines de la Edad Media, Valladolid, Junta de Castilla y León.

Diago Hernando, Máximo (1993b): Conflictos políticos en Ávila en las décadas precomuneras, "Cuadernos Abulenses", 19, pp. 69-101.

DiAgo HERNANDO, Máximo (1993c): Caballeros y ganaderos. Evolución del perfil socioeconómico de la oligarquía soriana en los siglos XV y XVL, "Hispania", 184, pp. 451-95.

Diago HeRnANDO, Máximo (1997): El papel de los linajes en las estructuras de gobierno urbano en Castilla y en el Imperio alemán durante los siglos bajomedievales, "En La España Medieval”, 20, pp. 143-177.

DiAgo HERNANDO, Máximo (2001): Evolución de las relaciones de poder en la región soriana durante el siglo XIV, en El siglo XIV: El Alba de una Nueva Era, Soria, Universidad Internacional Alfonso VIII, pp. 103-140.

«Anuario de Estudios Medievales», 32/2 (2002), pp. 879-913.- ISSN 0066-5061. 
EDWARDS, John (1982): Christian Cordoba. The City and its region in the Late Middle Ages, Cambridge.

GONZÁLEZ JiMÉNEZ, Manuel (1990): Ciudades y concejos andaluces en la Edad Media: Gobierno urbano, en Concejos y ciudades en la Edad Media Hispánica, "Actas del II Congreso de Estudios Medievales", Madrid, Fundación Sánchez Albornoz, pp. 377-98.

GUERRERO NAVARRETE, Yolanda (1986): Organización y gobierno en Burgos durante el reinado de Enrique IV de Castilla. 1453-1476, Madrid, Universidad Autónoma.

GUERRERO NAVARRETE, Yolanda (1998): Elites urbanas en el siglo XV: Burgos y Cuenca, "Revista d'Historia Medieval", 9, pp. 81-104.

Guerrero NAVArRete, Yolanda, y SÁnChez Benito, José María (1994): Cuenca en la baja Edad Media: Un sistema de poder, Cuenca, Diputación Provincial.

GUERRERo NAVARRETE, Yolanda, y SÁNCHEZ BENITO, José María (1997): Del concejo medieval a la ciudad moderna. El papel de las cartas expectativas de oficios ciudadanos en la transformación de los municipios castellanos bajomedievales: Burgos y Cuenca, en La Península Ibérica en la era de los descubrimientos 1391-1492, Sevilla, pp. 1013-1024.

HighField, J.R.L., y JeFFS, R. (1981): The Crown and Local Communities in England and France in the Fifteenth Century, Alan Sutton, Gloucester.

JARA FUENTE, José Antonio (1999): Sobre el concejo cerrado. Asamblearismo y participación política en las ciudades castellanas en la Baja Edad Media (Conflictos inter o intra-clase), "Studia Historica. Historia Medieval”, 17, pp. 113-36.

JARA FUENTE, José Antonio (2000): Concejo, poder y élites. La clase dominante de Cuenca en el siglo XV, Madrid, CSIC.

LADERO QUESADA, Manuel Fernando (1991): La ciudad de Zamora en la época de los Reyes Católicos. Economía y gobierno, Zamora.

LADERO QUeSADA, Miguel Ángel (1976): Historia de Sevilla. La ciudad medieval, Sevilla.

ÓPEZ BENITO, Clara Isabel (1983): Bandos nobiliarios en Salamanca, Salamanca.

PEZ VILlalBa, José Miguel (1992): Concejo abierto, regimiento y corregimiento en Guadalajara (1346-1546), "Espacio, Tiempo y Forma. Historia Medieval", 5 (1992), pp. 65-83.

LORENZO CADARSO, Pedro Luis (1994): Esplendor y decadencia de las oligarquías conversas de Cuenca y Guadalajara (siglos XVy XVI), "Hispania”, 186, pp. 53-94.

*Anuario de Estudios Medievales», 32/2 (2002), pp. 879-913.- ISSN 0066-5061. 
LOSA CONTRERAS, Carmen (1999): El concejo de Madrid en el tránsito de la Edad Media a la Edad Moderna, Madrid, Dykinson.

MACKAY, Angus (1978): Cultura urbana y oligarcas sevillanos en el siglo XV, en "Actas del I Congreso de Historia de Andalucía. Andalucía Medieval", Córdoba, pp. 163-171.

Márquez VILlanueVa, Francisco (1957): Conversos y cargos concejiles en el siglo $X V$, "Revista de Archivos, Bibliotecas y Museos", 2 , pp. 503-40.

Mensot, Denis (1985): L'élite du pouvoir à Murcia au Bas Moyen-Âge, en La ciudad hispánica durante los siglos XIII al XVI, Madrid, Universidad Complutense, vol. II, pp. 883-907.

Mignot, C. (1984): Le municipio de Guadalajara au XVe siècle. Système administratif et économique (1341-1567), "Anuario de Estudios Medievales", 14, pp. 581-609.

Mignot, C. (1988): El patriciado urbano de Guadalajara (1454-1502), en "Actas del I Congreso de Historia de Castilla La Mancha", Toledo, vol. VI, pp. 233-37.

MolÉNAT, Jean Pierre (1997): Campagnes et Monts de Tolède du XII au XV siècle, Madrid, Casa de Velázquez.

Monsalvo AnTón, José María (1988): El sistema político concejil. El ejemplo del señorio medieval de Alba de Tormes y su concejo de villa y Tierra, Salamanca, Universidad.

Monsalvo AnTón, José María (1990): La sociedad política en los concejos castellanos de la Meseta durante la época del regimiento medieval. La distribución social del poder, en Concejos y ciudades en la Edad Media hispánica, "II Congreso de Estudios Medievales", Madrid, Fundación Sánchez Albornoz, pp. 359-413.

MORENO NÚÑEZ, José Ignacio (1985): El regimiento de Toro en el siglo XV, en La ciudad hispánica durante los siglos XIII al XVI, Madrid, Universidad Complutense, pp. 773-795.

MORENo NúÑ̃EZ, José Ignacio (1992): Avila y su Tierra en la Baja Edad Media (Siglos XIII-XV), Junta de Castilla y León, Valladolid.

PINo GarCíA, José Luis del (1993): El concejo de Córdoba a fines de la Edad Media: estructura interna y política municipal, "HID", 20, pp. 355-401.

Pino Rebolledo, F. (1990): El concejo de Valladolid en la Edad Media (11521399), Valladolid.

RÁBADE OBRADÓ, María del Pilar (1990): Los judeoconversos en la Corte y en la época de los Reyes Católicos, Madrid, Universidad Complutense.

RUCQUOI, Adeline (1987): Valladolid en la Edad Media, 2 vols, Valladolid, Junta de Castilla y León.

«Anuario de Estudios Medievales», 32/2 (2002), pp. 879-913.- ISSN 0066-5061. 
RUCQUOI, Adeline (1995): Las oligarquías urbanas y las primeras burguesías en Castilla, en El Tratado de Tordesillas y su época, Junta de Castilla y León, Valladolid, t. I, pp. 345-370.

RUIZ DE LA PEÑA, José Ignacio (1969): Tránsito del concejo abierto al regimiento en el municipio leonés, "Archivos Leoneses", pp. 301-316.

SANTAMARÍA LuENGOS, José María (1993): Señorío y relaciones de poder en León en la Baja Edad Media (Concejo y cabildo catedral en el siglo XV), León, Universidad.

SÁNCHEZ LEÓN, Pablo (1998): Absolutismo y comunidad. Los orígenes sociales de la guerra de los comuneros de Castilla, Madrid, Ed. Siglo XXI.

Thompson, I.A.A. (1997): Patronato real e integración politica en las ciudades castellanas bajo los Austrias, en José Ignacio FORTEA PÉrEZ (Ed.), Imágenes de la diversidad. El mundo urbano en la Corona de Castilla (s. XVI-XVIII), Santander, Universidad de Cantabria, pp. 475-496.

TOMÁS Y VALIENTE, Francisco (1970): Origen bajomedieval de la patrimonialización y enajenación de oficios públicos en Castilla", en "Actas del I Symposium de Historia de la Administración", Madrid, pp. 125-59.

TORRES FONTES, J. (1963): El concejo murciano en el reinado de Alfonso XI, "Anuario de Historia del Derecho Español", 23, pp. 139-159.

TORRES FonTES, J. (1987): Evolución del concejo de Murcia en la Edad Media, "Murgetana", 71, pp. 5-47.

VALDEÓN BARUQUE, Julio (1990): Las oligarquías urbanas, en Concejos y ciudades en la Edad Media Hispánica, "Actas del II Congreso de Estudios Medievales”, Madrid, Fundación Sánchez Albornoz, pp. 507-21.

VELASCO GARCÍA, C (1987): Extracción social, relaciones y competencias de los regidores jienenses en el siglo $X V$, Jaén. 